\title{
DOMINACJA JĘZYKA ANGIELSKIEGO WE WSPÓLCZESNYM ŚWIECIE I JEJ WPLYW NA MOTYWACJE JEGO RODZIMYCH UŻYTKOWNIKÓW DO NAUKI JĘZYKÓW OBCYCH
}

SŁowA KLUCZOWE: język angielski, rodzimy użytkownik, dominacja, motywacja, języki obce

\section{Język angielski jako język rodzimy i obcy}

Nie ulega wątpliwości, że język angielski jest najpopularniejszym językiem obcym, jakiego uczą się ludzie na całym świecie, a zwłaszcza w Europie. Jak podaje Edwards [2004, s. 1], na całym świecie językiem tym posługuje się ponad miliard osób, w niektórych krajach jest on językiem większości, w innych jest on drugim językiem używanym dla celów ,, oficjalnych”, takich jak edukacja czy rząd, w jeszcze innych jest językiem obcym nauczanym w szkołach. (...) Źródło wysokiej pozycji języka angielskiego leży w tącznej liczbie osób, które się nim postuguja - native speakerów, osób, dla których jest on drugim językiem i tych, dla których jest językiem obcym ${ }^{1}$. Z kolei Crystall [1997, s. 3] dodaje, że jako języka obcego naucza się go w ponad stu krajach na świecie. Jenkins [2007, s. 2] stwierdza natomiast, że popularność tego języka, jego ekspansja, zyskuje na sile od połowy XX w. i jest to sytuacja bez precedensu. Warto w tym momencie zauważyć, że w przypadku języka angielskiego nie jest to dominacja (jedynie) sztucznie narzucona, proces ten charakteryzuje się swoim naturalnym biegiem. Można zaryzykować stwierdzenie, że angielskiego ucza się wszyscy; jak ponownie czytamy u Jenkins [tamże, s. 198], szybko rosnąca dominacja języka angielskiego jako głównego światowego lingua franca prowadzi do różnorodności sposobów władania tym językiem, tj. rośnie liczba osób mówiących po angielsku, ale język ten szybko traci swa narodowa bazę kulturalna i kojarzony jest z kultura globalna [Dörnyei i in., 2006, s. 9, za Jenkins, 2007, s. 198]. Jest on także międzynarodowym językiem biznesu. Jak pisze Vollstedt [Knapp i Meierkord 2002, s. 103], język ten jest nie tylko ,zewnętrznym” językiem komunikacji korporacyjnej, lecz także „wewnętrznym” - posługują się nim ludzie w ramach firm będących czę-

\footnotetext{
1 Tłumaczenie własne.
} 
ścią tych samych koncernów. Trudno się takiemu zjawisku dziwić, biorąc pod uwagę wspomnianą ekspansję i dominację. Po pierwsze, dominacja ta jest związana $\mathrm{z}$ faktem, iż właśnie tym językiem władają obywatele wielkich światowych potęg — takich jak Wielka Brytania i Stany Zjednoczone, ale, nie jest to oczywiście jedyny powód popularności, jaką cieszy się nauka języka angielskiego. Powodem, który zdaje się znacznie ważniejszy i bardziej logiczny jest to, że język angielski jest językiem stosunkowo łatwym do opanowania w stopniu wystarczającym do komunikacji codziennej, czy też biznesowej. Nie trzeba wielu lat nauki, by dość dobrze zacząć nim władać, dostęp do tego języka jest bardzo łatwy, ponieważ oferują go wszystkie niemal szkoły językowe, które, nie oszukujmy się, na nim gównie opierają swoją działalność, a inne języki obce, jakie szkoły tego typu mają w swojej ofercie, są przede wszystkim dodatkiem. Nie można im odmówić popularności, nie da się jej jednak porównać z popularnością języka angielskiego. Nie bez znaczenia jest także jego obecność w kulturze masowej - w telewizji, kinie, Internecie, oraz w kulturze wysokiej. Na co dzień się nad tym nie zastanawiamy, ale jesteśmy wręcz bombardowani anglojęzycznymi filmami i programami, niewiele zostałoby pozycji w programie telewizji, gdyby usunąć wszystkie te, w których obecny jest język angielski. Podobnie wygląda sytuacja $\mathrm{w}$ ofercie kin. Wiele anglojęzycznych słów i zwrotów wkrada się do języka, nie tylko polskiego, co z kolei składa się na globalny charakter języka angielskiego. Wszechobecność zapożyczeń z języka angielskiego w każdej dziedzinie życia zauważa także Ammon [2001, s. 9], co, jego zdaniem, związane jest $\mathrm{z}$ dominacją tego języka w środowisku nauki.

Sposobów na zachęcanie i motywowanie ludzi do uczenia się tego języka jest wiele, w czym udział swój mają także uczelnie wyższe, na których, jak pisze Ammon [2001, s. 9], zajęcia często prowadzone są po angielsku, aby przyciągnąć jak największą liczbę studentów zagranicznych, którzy niekoniecznie mają chęć uczyć się języka danego kraju.

\section{Wady i zalety hegemonii języka angielskiego z punktu widzenia native speakerów}

Wszystkie te elementy, świadczące o swoistej hegemonii języka angielskiego w czasach współczesnych, sprawiają, że rodzimi użytkownicy tego języka czują się na całym świecie w pewien sposób bezpieczni, ponieważ zdają sobie sprawę $\mathrm{z}$ uprzywilejowanej sytuacji, w jakiej się znajdują. Z naszego punktu widzenia jest to sytuacja godna pozazdroszczenia, ponieważ otrzymują oni pewnego rodzaju „klucz do świata" niejako w pakiecie. Są w stanie bez większych trudności porozumieć się niemal wszędzie, natomiast my musimy specjalnie się uczyć języków obcych, jeśli chcemy uzyskać podobny komfort komunikacji. Przewaga ta jest jednak tylko pozorna, ponieważ sprawia, że nauka języków obcych w krajach anglojęzycznych nie jest priorytetem, skoro ich obywatele są w stanie bez większych przeszkód porozumieć się właściwie wszędzie. Co za tym idzie, ich motywacja do nauki nie jest tak silna jak wśród obcokrajowców zgłębiających tajniki ich języka ojczystego. 
Należy zaznaczyć, że podobnie jak u nas, tak samo w krajach anglojęzycznych wśród przedmiotów szkolnych znajdują się języki obce, więc to nie tak, że rodzimi użytkownicy języka angielskiego nie otrzymują szansy zetknięcia się z nauką języków obcych. Cóż jednak z tego, skoro są świadomi światowej dominacji swojego języka ojczystego. Zwróćmy uwagę na to, jak silnej potrzebujemy motywacji wewnętrznej w sytuacji, kiedy tak naprawdę uczyć się języka nie musimy, kiedy znajomość języka obcego jest jedynie mile widzianym dodatkiem, bez którego można się obyć. Jednak nawet jeśli u rodzimego użytkownika języka angielskiego pojawi się motywacja do nauki języka obcego, co więcej - wyjedzie on nawet w tym celu do kraju, którego języka chce się uczyć, to na każdym kroku napotka utrudnienia. Co ciekawe, najczęściej nie wynikają one nawet ze złej woli ludzi, z którymi taka osoba się styka. Dzieje się bowiem tak, że w kontakcie z native speakerami ludzie uczący się języka angielskiego starają się wykazać swoją dotychczasową znajomością języka i korzystając z okazji obcowania z jego rodzimym użytkownikiem - tę znajomość pogłębić. Tym sposobem odbierają im jeden z najważniejszych elementów sprzyjających nauce języka obcego, jakim jest styczność z tym językiem. Nieświadomie wyrządzają im zatem wielką krzywdę, chociaż zjawisko to niekoniecznie postrzegane jest jako krzywda w przypadku tych mniej zmotywowanych do nauki jednostek. Wszystko to sprawia, że osoby anglojęzyczne znajdują się w pewnego rodzaju „,balonie bezpieczeństwa", który rodzi wyżej wspomniane paradoksy w sytuacji, gdy osoby te akurat chcą nauczyć się języka obcego.

Jak podaje Gajek [2008, s. 34], 53\% Europejczyków deklaruje znajomość jednego języka oprócz ojczystego, a 26\% twierdzi, że zna dwa języki oprócz ojczystego. Języki sq używane głównie na wakacjach, podczas ogladania filmów $i$ w rozmowach $w$ pra$c y$, są to jednak ogólnoeuropejskie statystyki, nie można zatem zakładać, że tyle osób zna język obcy w każdym kraju UE, tym bardziej, że ta sama autorka [Gajek, 2008, s. 35] pisze, że: 71\% Europejczyków zgadza się, że każda osoba w Unii Europejskiej powinna znać przynajmniej jeden język obcy, a 69\% twierdzi, że językiem tym powinien być język angielski, czym automatycznie stawia rodzimych użytkowników tego języka w uprzywilejowanej pozycji. Widać zatem jak głęboko zakorzenione w świadomości ludzi jest przekonanie o nadrzędności języka angielskiego w stosunku do innych języków - i mam tu zarówno na myśli native speakerów, jak i osoby, dla których język angielski jest językiem drugim bądź obcym. Rozgraniczenie pomiędzy językiem drugim a obcym podaję za Arabskim [1985, s. 6], który pisze, że najważniejsza różnica między językiem drugim i obcym polega na intensywności kontaktów z nim i na różnym stopniu motywacji, aby go przyswoić. (...) Wiele jest jednak cech wspólnych $w$ obu procesach $i$ stad, gdy nie zachodzi potrzeba ich rozróżniania, nazywamy oba procesy L2 lub językiem drugim. W przypadku osoby anglojęzycznej uczącej się nowego języka możemy bowiem mieć do czynienia z jednym i drugim przypadkiem - kiedy osoba taka emigruje do innego kraju na stałe jej motywacja wzrasta i z czasem poznawany język obcy może stać się dla niej językiem drugim. 


\section{Osoby anglojęzyczne a nauka języków obcych}

Chcąc skupić się na nauce języków obcych w przypadku osób anglojęzycznych, warto przede wszystkim zastanowić się nad elementami, które mogą z ich punktu widzenia mieć efekt najsilniej motywujący. Z logicznego sposobu rozumowania wynika, że takim elementem powinien być wyjazd do innego kraju, na dłużej (np. wyjazd związany z pracą zawodową), a zwłaszcza na stałe. Jednakże, w tym pierwszym przypadku znajomość nowego języka może wcale nie być konieczna, jeżeli w środowisku pracy dana osoba dalej może używać języka angielskiego. Pozostają natomiast sytuacje życia codziennego, w których znajomość języka tubylców jest wskazana (np. robienie zakupów). Ułatwieniem jest w tym momencie fakt, że stosunkowo szybko można opanować najpotrzebniejsze zwroty, by bez większych problemów radzić sobie w przypadku, gdy język angielski może nie wystarczyć. Jednakże, tu znowu może pojawić się problem, wpływający na obniżenie motywacji: jeżeli dana osoba w swoim przekonaniu osiągnie „niezbędne minimum językowe”, dochodzi ona do wniosku, że taka znajomość języka jej wystarczy, bądź też dalsza nauka może wydawać się zbyt trudna. Kolejnym utrudnieniem (z punktu widzenia osoby uczącej się języka), a jednocześnie ułatwieniem (jeżeli bierzemy pod uwagę aspekt wygody) jest to, że w razie potrzeby rodzimy użytkownik języka angielskiego może liczyć na osoby władające jego językiem, co automatycznie eliminuje poważniejsze problemy z komunikacją (np. wizyta u lekarza, w urzędzie, bardziej skomplikowane zakupy itd.). Oczywiście, w przypadku osiedlenia się na stałe w obcym kraju, nauka języka w nim obowiązującego prędzej czy później staje się konieczna, ale tutaj sprzymierzeńcem jest czas - im dłużej człowiek przebywa w danym miejscu, tym lepiej poznaje zwyczaje tam panujące i wreszcie - język, z którym ma coraz większość styczność, nawet jeśli spotyka wiele osób mówiących po angielsku. Warto bowiem zauważyć, że po pewnym czasie kontakty tylko z osobami władającymi językiem angielskim przestają wystarczać i człowiek taki, o ile nie chce czuć się zależny językowo od innych, staje się bardziej zmotywowany do nauki języka obcego, tym bardziej wtedy, kiedy już się z nim osłuchał, poznał podstawy, na których może oprzeć dalszą naukę. Nie bez znaczenia jest także zaznajomienie się z samym krajem, w którym się przebywa, jego kulturą, tradycjami, te elementy także są sprzymierzeńcami dla osoby uczącej się języka. Jak o sytuacji w Polsce pisze Gębal [2010, s. 18], poza realizacją zajęć z kultury polskiej jako obcej mamy do czynienia coraz częściej w naszej rzeczywistości edukacyjnej z potrzeba organizacji zajęć dla przybyłych do naszego kraju emigrantów, z czego wynika, iż są to właśnie elementy zajęć dla obcokrajowców — nie tylko nauka języka, ale także zaznajamianie przybyłych do Polski osób o jej kulturze, historii oraz tradycjach.

Nieco inaczej sytuacja wygląda w przypadku anglojęzycznych native speakerów, którzy mają partnerów z innych krajów. Wówczas także może u anglojęzycznej osoby pojawić się motywacja do nauki nowego języka, jednak nie zawsze okazuje się ona wystarczająco silna, by taki zamiar wcielić w życie. Pojawia się tutaj problem już wcześniej wspomniany — to ta druga osoba, już władająca językiem 
angielskim, dostosowuje się do swojego partnera i niekoniecznie wymaga od niego, by uczył się jej języka ojczystego, zwłaszcza wtedy, gdy oboje mieszkają w kraju anglojęzycznym. U takiej osoby motywacja do nauki języka obcego jest co prawda wyższa niż u przeciętnego native speakera, ale pojawiają się wspomniane elementy utrudniające naukę - m.in. „balon bezpieczeństwa”, kiedy to otoczenie dostosowuje się do osoby anglojęzycznej, a nie odwrotnie. Tym sposobem koło się zamyka.

Kolejnym elementem motywującym osoby anglojęzyczne do nauki języków obcych mogą być studia za granicą. Jednak, jak wspomniane było wcześniej, tutaj utrudnieniem jest fakt, że wiele zajęć jest prowadzonych w języku angielskim i jest on najczęściej wystarczający do komunikacji na uczelni, a nawet poza nią, ponieważ mamy wówczas do czynienia ze wspomnianym już zjawiskiem dostosowywania się otoczenia do osoby anglojęzycznej. Warto także zauważyć, że problem ten dotyczy nie tylko anglojęzycznych native speakerów, lecz też osób, dla których język ten jest językiem drugim (obcym). Tutaj jeszcze bardziej widoczny jest problem dostosowywania się otoczenia do takich osób, a ich motywacja do nauki nowego języka (zwłaszcza tak trudnego jak język polski) może być mniejsza, ponieważ ludzie ci już włożyli wysiłek w naukę języka obcego, jakim dla nich był język angielski, czują się więc w pewien sposób usprawiedliwieni i oczekują, że dzięki znajomości tego języka mogą porozumieć się na całym świecie. Ten najważniejszy (w ich przekonaniu) język obcy już poznały, inne języki mogą być przydatne, ale zawsze są one najwyżej dodatkiem. Stąd może wynikać ich niechęć do nauki nowych, „niepotrzebnych” języków, chociaż oczywiście innych języków także się uczą w zależności od możliwości i zainteresowań, ale już nie na taką skalę.

I wreszcie, pozostaje ostatnia grupa osób anglojęzycznych uczących się języków obcych, a mianowicie - osoby szczególnie zainteresowane tą tematyką. Jak powszechnie wiadomo, każda dziedzina ma swoich pasjonatów, znajdą się zatem i tacy, którzy będą się chcieli uczyć języków obcych i będzie to wynikało z ich wewnętrznej motywacji, która może mieć najróżniejsze źródła. Takie osoby, mimo że nie unikną wcześniej wspomnianych problemów, zapewne najlepiej będą sobie z nimi radzić, ponieważ będą bardziej świadome językowo, tj., lepiej zorientowane w towarzyszących nauce przeszkodach i przygotowywane na radzenie sobie z nimi.

\section{Podsumowanie}

Na koniec chciałabym zacytować słowa Bugajskiego na temat tożsamości człowieka, wynikającej z języka, jakim się posługuje:

[...] tożsamość językowa jest jednym z najważniejszych, a może nawet najważniejszym czynnikiem kształtującym tożsamość człowieka. Trudno jednak mówić o jakiejkolwiek tożsamości bez uświadomienia jej sobie. O tym, czy jesteśmy Europejczykami, Polakami, zielonogórzanami, decyduje świadomość i wewnętrzne przekonanie o naszej europejskości, polskości, „zielonogórskości”, czyli świadomość przynależności do wspólnoty.

[Bugajski, 2006, s. 61] 
Władanie językiem angielskim sprawia, że ludzie automatycznie czują, że przynależą do znacznie większej wspólnoty niż te mniejsze, wspomniane w cytacie, „lokalne” wspólnoty. Niemniej jednak, każdy z nas pragnie gdzieś przynależeć. Język angielski natomiast daje poczucie przynależności do wspólnoty w pewien sposób elitarnej, światowej. Osoby anglojęzyczne są tego świadome, dlatego tak trudno u nich o motywację do nauki języków obcych, zwłaszcza że tą samą energię mogłyby poświęcić na zdobywanie bardziej przydatnych, w ich przekonaniu, umiejętności. Jak ponadto czytamy u wspomnianego wyżej autora [Bugajski, 2006, s. 61]: W ostatnich czasach ukształtowały się i wyrazistości nabraty takie pojęcia, jak 'Unia Europejska' i 'wspólna Europa'. Tu także prym wiedziejęzykangielski. Jego „ogólnoeuropejskość”, czy wręcz „ogólnoświatowość” przyczynia się do pogłębiania dominacji tego języka, która jest niekwestionowana. Niemniej jednak, jeżeli chcemy spojrzeć na to zjawisko i problemy, jakie stwarza ono w przypadku osób anglojęzycznych, które chcą poznać nowy język, należy sobie uświadomić te wszystkie przeszkody, jakie pojawiają się na ich drodze. Dopiero wtedy można je chociaż częściowo wyeliminować. Język angielski, mimo że wydaje się „kluczem do świata”, może stać się pułapką, która uwięzi nas pod kloszem i sprawi, że dojdziemy do wniosku, iż wiemy już wszystko i inne języki nie są nam tak bardzo potrzebne. To z kolei stawia inne języki w niekorzystnym, a może nawet nieco niebezpiecznym położeniu. Motywacji do nauki języka trzeba natomiast szukać, gdzie tylko jest to możliwe, jednak zawsze najsilniejszą motywacją będzie ta płynąca z nas samych i — paradoksalnie —otwartość na świat.

\section{Bibliografia}

Ammon U., 2001, Editor's Preface [w:] tegoż (red.), The Dominance of English as a Language of Science. Effects on Other Languages and Language Communities, Berlin-New York, s. 5-9.

ARABSKI J., 1985, O przyswajaniu języka drugiego (obcego), Warszawa.

Bugajski M., 2006, Język w komunikowaniu, Warszawa.

Crystall D., 1997, English as a Global Language, Cambridge.

EDWARDS V., 2004, Multilingualism in the English-speaking World, Oxford.

Dörnyei Z., Csizér K., Németh N., 2006, Motivation, Language Attitudes and Globalisation, Clevedon.

GAJEK E., 2008, Edukacja językowa w Unii Europejskiej. Informator i przewodnik internetowy dla nauczycieli, Warszawa.

GĘBAL P., 2010, Dydaktyka kultury polskiej w ksztatceniu językowym cudzoziemców, Kraków.

JenKIns J., 2007, English as a Lingua Franca: Attitude and Identity, Oxford.

Vollstedt M., 2002, English as a language for internal company communications

[w:] Lingua Franca Communication, Knapp K., Meierkord C. (red.), Frankfurt am Main, s. 87-107. 